\title{
The pulmonary pathology of COVID-19
}

\author{
Hans Bösmüller ${ }^{1}$ (D) $\cdot$ Matthias Matter $^{2} \cdot$ Falko Fend $^{1} \cdot$ Alexandar Tzankov $^{2}$
}

Received: 14 December 2020 / Revised: 1 February 2021 / Accepted: 3 February 2021 / Published online: 19 February 2021

(C) The Author(s) 2021

\begin{abstract}
The lung is the main affected organ in severe coronavirus disease 2019 (COVID-19) caused by the novel coronavirus SARS$\mathrm{CoV}-2$, and lung damage is the leading cause of death in the vast majority of patients. Mainly based on results obtained by autopsies, the seminal features of fatal COVID-19 have been described by many groups worldwide. Early changes encompass edema, epithelial damage, and capillaritis/endothelialitis, frequently combined with microthrombosis. Subsequently, patients with manifest respiratory insufficiency exhibit exudative diffuse alveolar damage (DAD) with hyaline membrane formation and pneumocyte type 2 hyperplasia, variably complicated by superinfection, which may progress to organizing/fibrotic stage DAD. These features, however, are not specific for COVID-19 and can be found in other disorders including viral infections. Clinically, the early disease stage of severe COVID-19 is characterized by high viral load, lymphopenia, massive secretion of proinflammatory cytokines and hypercoagulability, documented by elevated D-dimers and an increased frequency of thrombotic and thromboembolic events, whereas virus loads and cytokine levels tend to decrease in late disease stages, when tissue repair including angiogenesis prevails. The present review describes the spectrum of lung pathology based on the current literature and the authors' personal experience derived from clinical autopsies, and tries to summarize our current understanding and open questions of the pathophysiology of severe pulmonary COVID-19.
\end{abstract}

Keywords SARS-CoV-2 $\cdot$ COVID-19 $\cdot$ Diffuse alveolar damage $\cdot$ Pulmonary disease $\cdot$ Autopsy

Since the outbreak of severe respiratory infections caused by the novel coronavirus termed SARS-CoV-2 in Wuhan, China, in the end of 2019 [1], the pandemic has resulted in more than 110 million confirmed infections and more than 2.4 million deaths worldwide (February 2021), with true numbers likely much higher.

Although SARS-CoV-2 infection is considered a systemic disease and may affect virtually every part of the body, the central finding and the primary cause of death in most cases of severe COVID-19 is lung damage. Results obtained from

Hans Bösmüller, Matthias Matter, Falko Fend and Alexandar Tzankov contributed equally to this work.

Falko Fend

falko.fend@med.uni-tuebingen.de

$\triangle$ Alexandar Tzankov

Alexandar.Tzankov@usb.ch

1 Institute of Pathology and Neuropathology, University Hospital Tübingen and Eberhard Karls University Tübingen,

Liebermeisterstraße 8, 72076 Tübingen, Germany

2 Pathology, Institute of Medical Genetics and Pathology, University Hospital Basel, University of Basel, Basel, Switzerland autopsies have been crucial for the identification of pathomechanisms of lethal COVID-19 and have provided important information for treatment approaches. Despite the recent emergence of COVID-19, significant advances have already been made in understanding of this viral infection and its sequelae, although it has to be acknowledged that much has still to be learned about this novel disease. This review briefly summarizes the current knowledge of pulmonary COVID-19 pathology and pathophysiology and draws on the experience of the authors obtained from autopsies of fatal COVID-19.

\section{The pulmonary pathology of fatal COVID-19}

In most individuals, COVID-19 is characterized by flu-like symptoms caused by the viral infection itself. A subset of patients develops acute lung injury (ALI), also called pneumonia, frequently accompanied by coagulopathy. The majority of patients with severe COVID-19 are elderly males (M:F ratio $2: 1-3: 1$ ), with a mean age of $73-81.5$ years in autopsy cohorts, and a range from 31 to 96 years [2,3]. The majority of individuals show one or several comorbidities, including 
hypertension, atherosclerosis, ischemic cardiomyopathy and/or coronary heart disease, chronic obstructive pulmonary disease, diabetes, ATTR amyloidosis, and obesity [4-6]. Pulmonary damage is the dominant feature in most cases of severe COVID-19 and the primary cause of fatal outcome. Mainly based on autopsy series, including socalled minimally invasive autopsy using post-mortem transthoracic or transbronchial necropsy [7-9], the seminal pathological features, and the time course and evolution of pulmonary alterations, have been described, and underlying pathomechanisms are being investigated [10-16].

Pulmonary COVID-19 can be subdivided into 4 main morphological stages, including (1) an early stage (day 0-1) with edema, incipient epithelial damage, and capillaritis/ endothelialitis, (2) the stage of exudative diffuse alveolar damage (DAD) (days 1-7), and (3) the organizing (1 to several weeks) and (4) the fibrotic stage of DAD (weeks to months) (Fig. 1). Although this indicates an orderly progression along the different stages, and the fibrotic stage is usually associated with long-standing severe disease, it needs to be emphasized that different DAD manifestations frequently coexist side by side, a reflection of the marked spatial and temporal heterogeneity of COVID-19 [10,11, 17]. Among the determinants of pulmonary pathology in severe COVID-19 are time from onset of disease, comorbidities, the extent of intensive therapeutic measures including mechanical ventilation, and the presence or absence of superinfection. Descriptions of early-stage pulmonary COVID-19 are very limited (virtually based on a handful cases) and include incidental findings in lobectomy specimens from patients undergoing surgery for lung cancer. Focal edema, epithelial damage and pneumocyte hyperplasia, desquamation of alveolar macrophages, and capillaritis/ endothelialitis were among the reported findings, although it is not clear whether these are related to SARS-CoV-2 infection $[18,19]$. In the few published fatal cases early after infection, neutrophilic capillaritis, capillary microthrombosis, massive pulmonary edema, and signs of early epithelial damage but little interstitial or alveolar inflammation were observed (Fig. 1a) $[12,20]$. These pulmonary microvascular changes are an important feature of COVID-19, and may contribute to hypoxemia and acute cardiac failure [21].

Gross examination of the lungs usually shows an increased weight with edema and diffuse congestion, and cut surfaces with irregularly distributed regions of consolidation, and-in a subset of cases - areas of hemorrhage or infarction, frequently with visible thrombosis in feeder vessels [11]. Of note, infarcts frequently lack the typical wedge shape, possibly due to thrombotic occlusion of multiple vessels rather than a single embolus. Pleural effusion is uncommon in COVID-19 [17].

Histologically, in the exudative phase of DAD, the alveolar spaces contain fibrin-rich edematous fluid, an increase in macrophages with occasional multinucleated giant cells of epithelial origin, but without viral inclusions, and variably
Fig. 1 Pulmonary pathology of fatal COVID-19. a Incipient pulmonary damage in early-stage disease with intraalveolar edema, endothelial necrosis, microthrombosis, and endothelialitis. Insert with progressive inflammatory vascular injury with nuclear debris and granulocytes. (HE $\times 100)$ b Pneumocyte type 2 hyperplasia in exudative phase of DAD. $(\mathrm{HE} \times 100)$ c Multiple intraalveolar giant cells in exudative phase DAD. $(\mathrm{HE} \times 100)$ d Hyaline membranes and solid fibrin deposits in exudative phase DAD $(\mathrm{HE} \times 100)$ e Thrombosis in small- to medium-sized vessels in early-stage lung disease $(\mathrm{HE} \times 100) \mathbf{f}$ Invasive aspergillosis as rare type of superinfection in late-stage DAD. $(\mathrm{HE} \times 100) \mathbf{g}$ Interstitial and intramural fibrosis and intraalveolar plugs of loose connective tissue in organizing phase of DAD. $(\mathrm{HE} \times 100) \mathbf{h}$ Massive bronchopulmonary squamous metaplasia in late stage organizing DAD. $(\mathrm{HE} \times 100)$

prominent hyaline membranes (Fig. 1c, d) [12, 16, 22]. Intraalveolar hemorrhage is frequently observed, usually in association with thrombotic vessel occlusions and/or superinfections (Fig. 1e, f). Areas of dilated alveolar ducts and collapsed alveoli can occur side by side. Epithelium shows frequent necrosis, associated with marked type 2 pneumocyte hyperplasia, including atypical regeneration (Fig. 1b). A common feature are platelet-fibrin thrombi in capillaries and small arterial vessels, with occasional intravascular megakaryocytes [23], sometimes accompanied by significant vascular inflammation. Of note, neither the increase in intrapulmonary megakaryocytes nor microthrombotic disease is specific for COVID-19, but has been observed in DAD of other causes $[23,24]$. According to a recent summary of published autopsy cases, microthrombi were observed in 57\% of COVID-19, $58 \%$ of SARS, and $24 \%$ of H1N1 cases [24]. Thrombosis of large and intermediate-sized vessels, mostly arteries, associated with diffuse endothelial damage is a prominent but again not a specific feature of COVID-19 (Fig. 1e) [11-13, 24]. In addition, pulmonary embolism associated with deep venous thrombosis as a result of the pro-coagulatory state in COVID-19 has been described in up to $20 \%$ of patients and may be the direct cause of death $[13,25,26]$. Pulmonary infarction has been reported in $15-75 \%$ of patients in autopsy series [22, 24, 26].

Bronchopneumonia as an indication of bacterial or less commonly fungal superinfection has been described in 32 $57 \%$ of patients in the larger autopsy series [22, 24, 26], although it is currently unclear how frequently superinfection has to be regarded as cause of death.

Data on the composition of the inflammatory cell component are in part contradictory, probably reflecting both the lack of standardized, systematic examinations and the significant heterogeneity of the host response. The exudative phase is represented by $\mathrm{CD} 3$-positive lymphocytes and occasional plasma cells, infiltrating the interstitial space; a large number of CD68-, CD163-, and CD206-positive macrophages are mainly localized in the alveolar lumina $[27,28]$. Granulocytes are usually involved in vascular thromboinflammation and formation of neutrophilic extracellular traps (NETs; see later), but are not a dominant population 

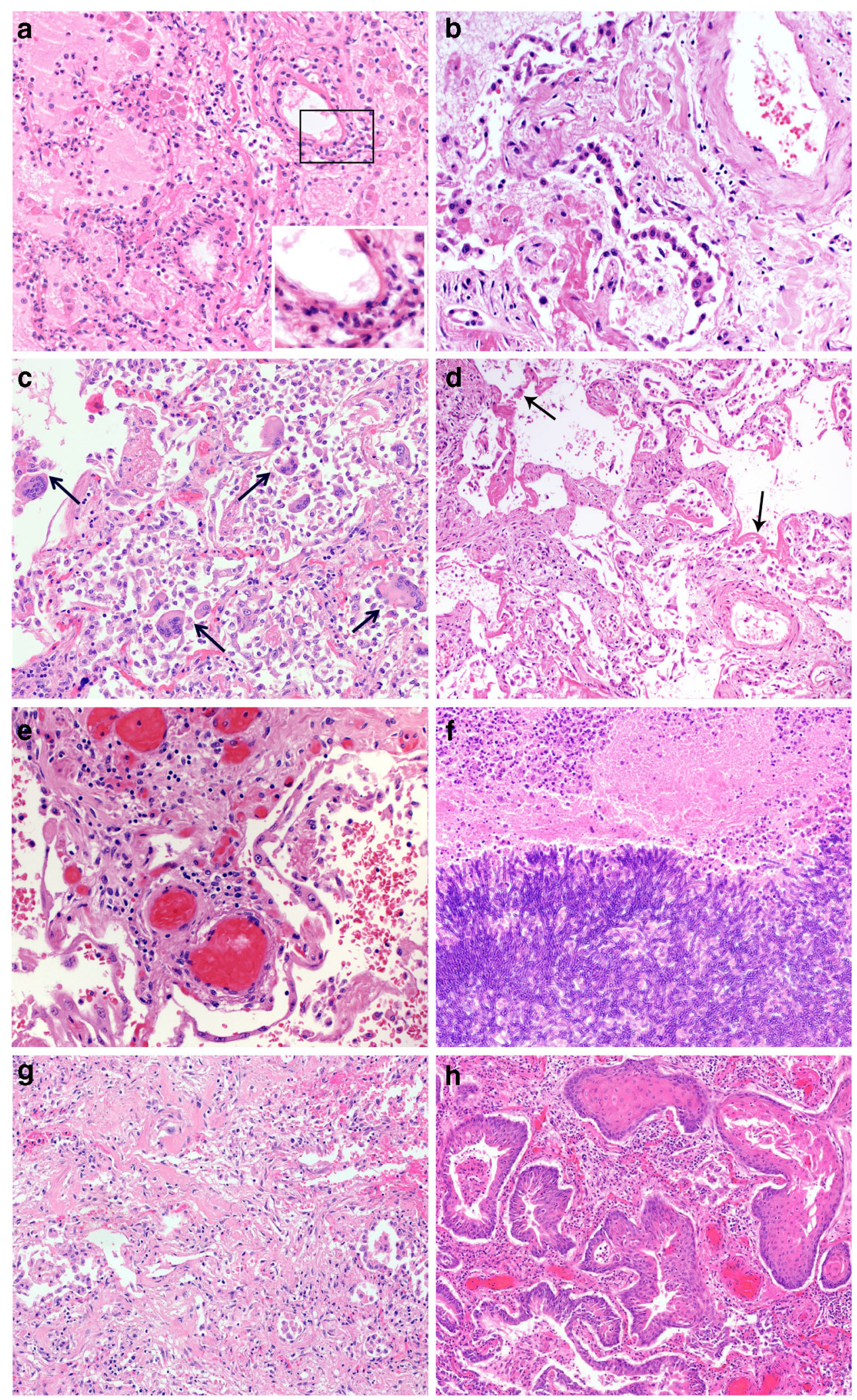

in the alveoli, unless there is superinfection. Using a variety of analytical platforms, several studies have highlighted the temporal and spatial heterogeneity of the inflammatory response in COVID-19 and defined two basic patterns. The first is considered the earlier disease phase and is characterized by high viral load, high expression of interferon pathway genes, 
and a dominance of M1-like macrophages, where the second pattern with low viral load is more heterogeneous in terms of gene expression profile and cellular composition, reflecting differences in evolution of DAD [29, 30]. Of note, much of what is described above in terms of tissue damage, remodeling, and inflammation is not specific for COVID-19 but rather a reflection of the specific type of ARDS with different etiologies.

Late-stage DAD is characterized by organizing changes merging into interstitial myofibroblastic proliferations, septal collagen deposition, development of loose alveolar plugs of fibroblastic tissue, and mural fibrosis (Fig. 1g). At this stage, bronchopulmonary metaplasia with squamous cells is frequently observed (Fig. 1h) [11, 31]. Of note, the 3 patterns described above can occur simultaneously in different areas of the lung and do not reflect a consistent chronological evolution. This spatial heterogeneity and the frequent presence of thrombosis and pulmonary embolism somehow limit the diagnostic value of minimally invasive autopsy described above.

\section{Correlation with clinical and radiological features}

Although the correlation of pathological findings with clinical and radiological characteristics is well beyond the scope of this review, knowledge of the seminal features is important for the pathologist. As described below in more detail, severe COVID19 is characterized by virally induced hyperactivation of the innate immune system resulting in a cytokine storm in early phases of the disease, with striking increases of C-reactive protein, IL1- $\beta$ and IL-6 [32,33], lymphopenia, and a profound vascular dysfunction resulting in hypercoagulability and thromboinflammation, reflected by increased D-dimer levels in almost all patients and an increased incidence of both venous and arterial thrombosis and pulmonary thrombembolism [34]. The late stage of the disease is dominated by DAD and its complications, including progressive respiratory insufficiency and frequent superinfections $[29,30,32]$.

The most frequent radiological manifestation of COVID19 is ground-glass opacities (GGO) [35]. GGO is defined as increased attenuation on chest $\mathrm{CT}$, which does not obscure the bronchovascular structures. Bilateral lung involvement is typical, and the right lower lobe is the most commonly affected area. Since the pathogen is inhaled with respiratory droplets, and pulmonary infection may be reinforced through active viral replication in the upper and lower respiratory tract [36], the disease is usually in bronchocentric distribution. As the disease progresses, GGO may disappear or may become more confluent and widespread and evolve into frank consolidation. Histology correlates with the imaging patterns. GGO with reticular interstitial thickening in $\mathrm{CT}$ is associated with mid-
Fig. 2 Scheme of the putative pathophysiological mechanisms of SARSCoV-2 induced acute lung injury, mainly diffuse alveolar damage (background microphotograph (5); H\&E, $\times 200$ ), and microangiopathy and immunopathology in lethal (severe) COVID-19. Inserts, except for (1), are visualized by immunoperoxidase, microphotographed at $\times 400$, and represent (1) SARS-CoV-2 in situ hybridization with the 845701 RNAscope probe - V-nCoV2019-S-sense and visualized with the RNAscope 2.5. LS detection kit (brown) from Advanced Cell Diagnostics (Hayward, CA, USA), yielding linear positivity of an alveolar septum; (2) immunohistochemical staining for SARS-CoV-2 Spike protein with the clone 007 from Sino Biological (Wayne, PA, USA), showing protein deposition on the inner side of an alveolar capillary; (3) immunohistochemical staining for fibrin with a polyclonal antibody A0080 from Dako (Glostrup, Denmark), revealing fibrin microthrombi casting the alveolar capillary network; (4) immunohistochemical staining for myeloperoxidase with a polyclonal antibody 760-2659 from Roche/ Ventana (Rotkreuz, Switzerland), with neutrophilic granulocytes stuck into an alveolar capillary and displaying microscopic figures suggestive of neutrophilic extracellular traps (NET); (6) immunohistochemical staining for CD105 with the clone EPR10145-10 from Abcam (Cambridge, UK), showing a tight network of newly formed vessels in an alveolar septum; (7) immunohistochemical staining for CD206 with the clone E2L9N from Cell Signaling (Danvers, MA, USA), with significant amounts of intraalveolar M2 macrophages. (8) Kyoto Encyclopedia of Genes and Genomes (KEGG) diagram of disturbed fluid share stress pathways in COVID-19; respective gene expression profiles have been obtained on 25 lethal COVID-19 cases and compared to lungs of 5 patients suffering from arterial hypertension and 5 histopathologically unremarkable autopsy lungs that served as controls, utilizing the HTG EdgeSeq Oncology Biomarker Panel (HTG Molecular Diagnostics, Tucson, AZ, USA). The scheme should be looked at clockwise from 11 to 7 . In general, upregulated genes/proteins are outlined in red, downregulated in green, indifferent ones in black

phase $\mathrm{DAD}$, whereas the consolidation pattern is mainly associated with late-phase DAD. Our own observations suggest that GGO and consolidations correlate with multiple pathologic processes, notably DAD, capillary dilatation and congestion, and microthrombosis. Acute superposed bronchopneumonia is more frequently associated with bronchial wall thickening and consolidation and vascular enlargement sign; capillary dilatation and congestion are tightly linked to microthrombosis [37]. Discrepancies between histologic and CT findings may in part be explained by lapse between CT scan and death or superimposed bronchopneumonia [38].

\section{SARS-CoV-2}

SARS-CoV-2, the causative agent of COVID-19, belongs to the family of coronaviruses, single-stranded positive-sense RNA viruses, with a diameter of $80-120 \mathrm{~nm}$ [39]. Two other coronaviruses, severe acute respiratory syndrome coronavirus (SARS-CoV) and Middle East respiratory syndrome coronavirus (MERS-CoV), can also cause ALI resulting in adult respiratory distress syndrome (ARDS). Infections show many similarities in clinical presentation and pathological findings. 


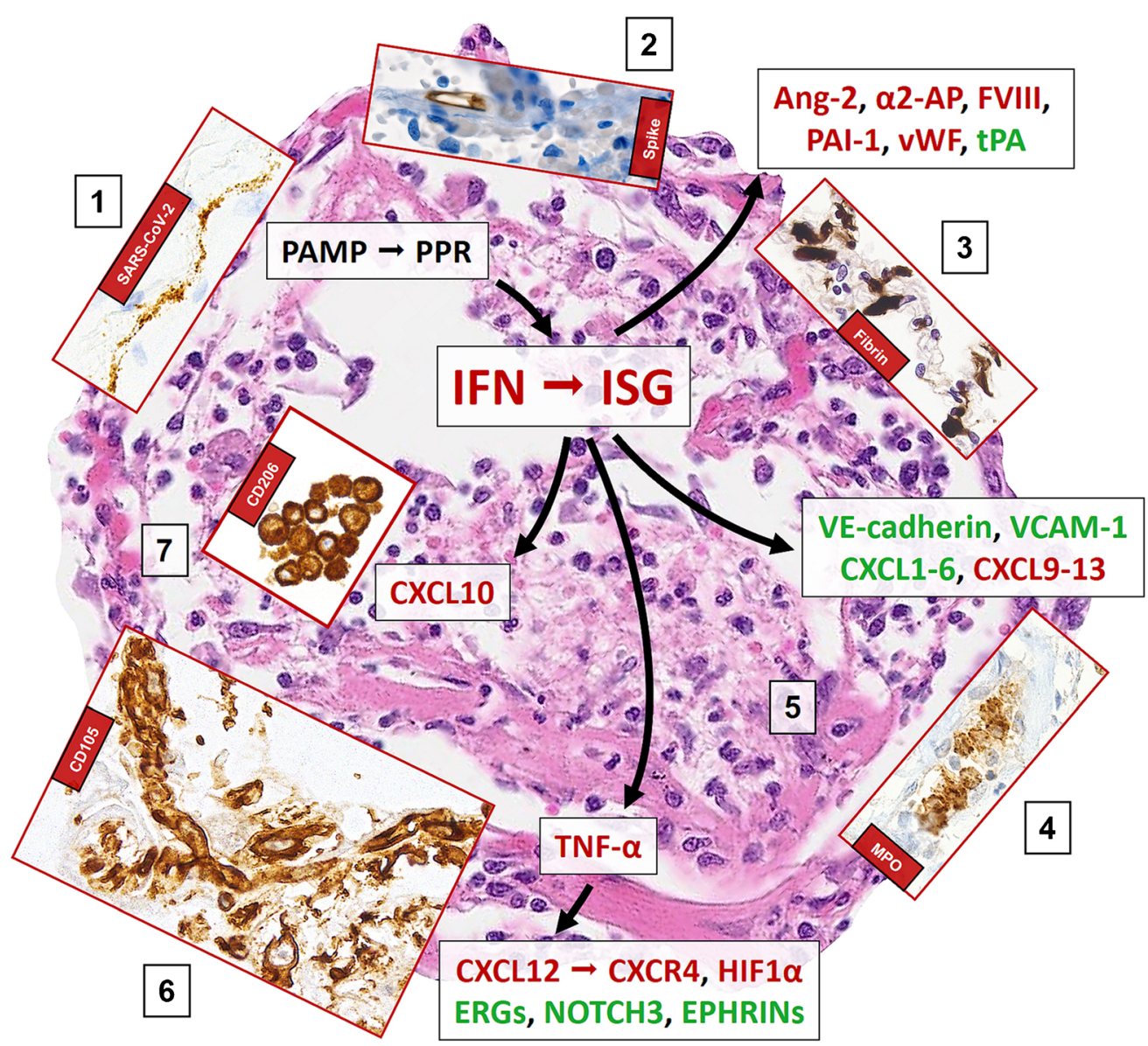

1. SARS-CoV-2

infection of

alveolocytes

(endothelial cells?)

2. SARS-CoV-2

spike-protein

deposition on

endothelial cells

3. Thrombotic

angiopathy

of alveolar

capillaries

4. Neutrophil extracellular traps in

capillaries

5. Exudative diffuse alveolar damage

6. Intussusceptive angiogenesis

7. M2-polarization of macrophages \& proliferative diffuse alveolar damage

8. Dysregulation, mainly downregulation, of fluid shear stress pathway coding genes

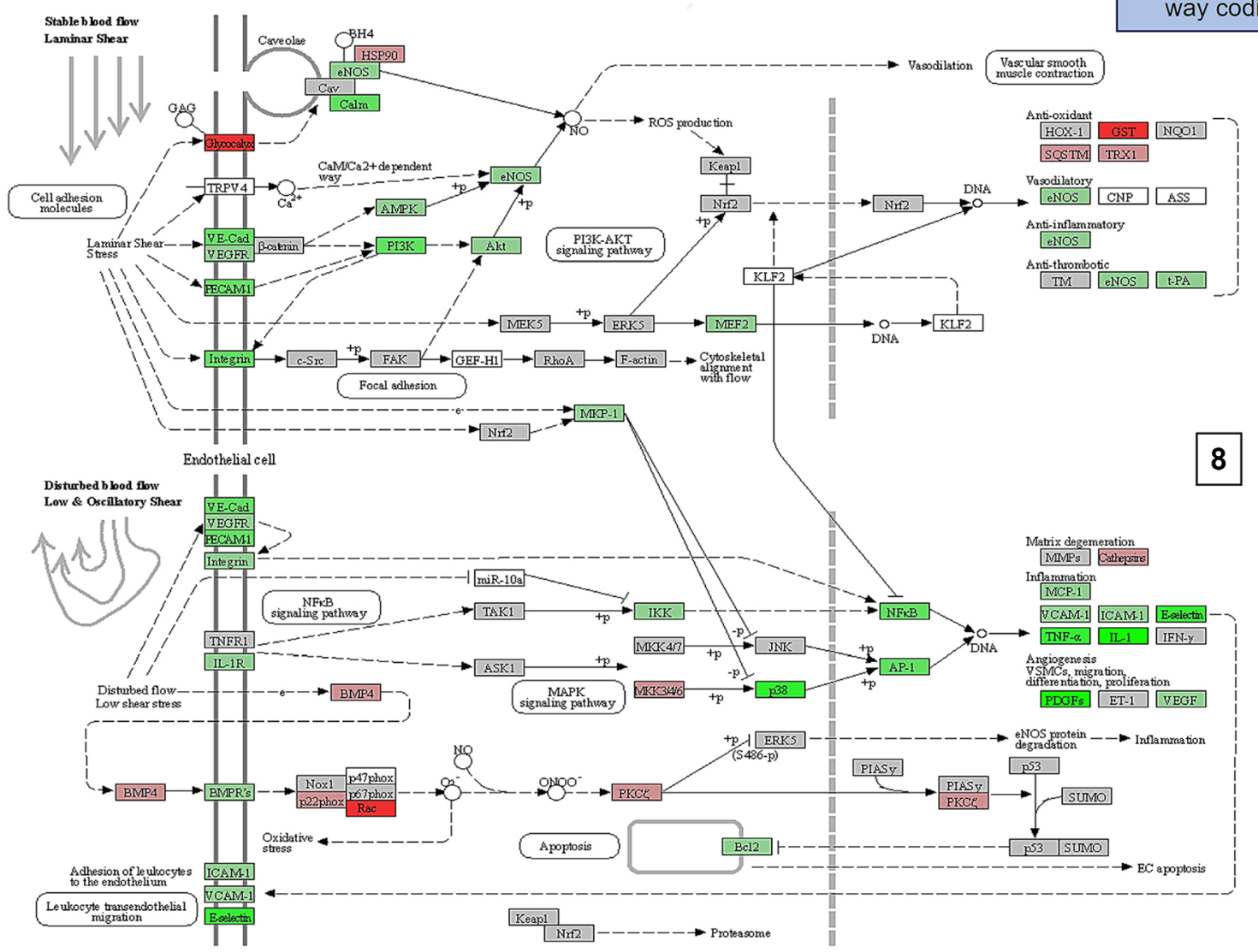


In the few autopsies of patients, who died from SARS, the predominant pattern of ALI was DAD, including exudative and proliferative phases, inflammatory infiltrates, edema, pneumocyte hyperplasia, and fibrinous exudate. Similar to COVID-19, a prominent vascular endothelial injury and extensive ALI has been observed. Autopsy studies of patients, who died from MERS, are very limited. The ALI is characterized by exudative DAD, pneumocyte hyperplasia, and septal inflammatory infiltrate [40].

\section{Viral entry and the cellular tropism in the lung}

SARS-CoV-2 enters the host cell through the interaction of angiotensin-converting enzyme 2 (ACE2) with the viral spike (S) protein supported by the activity of the transmembrane protease serine subtype 2 (TMPRSS2) [41]. This allows SARS$\mathrm{CoV}$ and SARS-CoV-2 to predominantly infect ciliated bronchial epithelial cells [42] and, by extension, type 2 pneumocytes (Fig. 2) as has previously been shown for SARS-CoV [43]. Consequently, virus particles are mainly detected in the epithelium of the upper respiratory tract and in the lung tissue [44]. They are mainly localized along plasmalemmal membranes and within cytoplasmic vacuoles, as described for other coronaviruses. The predominant infected cell types are type 2 and type 1 pneumocytes. In line with previous reports showing endothelial expression of ACE2 [42], viral inclusion particles have been detected in endothelial cells as well [20, 21, 28, 45]. Though this finding is still discussed controversially, as shown in Fig. 2, SARS-CoV-2 S proteins (without spike RNA) are present on endothelial cells especially with the Sino Biological antibodies clone 40150-R007 and the polyclonal one 40150-T62 [46, 47], which - though being a matter of discussion [48] - may provide another potential pathogenetic mechanism of COVID-19 endothelialitis [49].

The evidence to date suggests that the viral load in the respiratory tract samples peaks around symptom onset and decreases within 1 to 3 weeks. Although the duration of detection and the viral load differs between patients, viral RNA generally becomes undetectable (from upper respiratory tract specimens) about 2 weeks after symptom onset (median 14.5 days). For lower respiratory tract samples, there is conflicting evidence regarding the timing of peak viral loads and duration of virus detection, with some evidence suggesting that it occurs later and the duration of detection is longer compared with upper respiratory tract samples (median 15.5 days) [50]. Indeed, there is some evidence that viral RNA may still present in the lungs when throat swabs become negative [51].

RNA tests can confirm the diagnosis of SARS-CoV-2 (COVID-19) cases with real-time RT-PCR or next-generation sequencing. At present, nucleic acid detection techniques are considered an effective diagnostic method in clinical cases of COVID-19 [52, 53]. More recently, other advanced diagnostics have been designed and developed for the detection of
SARS-CoV-2. A reverse transcriptional loop-mediated isothermal amplification (RT-LAMP) has been established for rapid and colorimetric detection of this virus. RT-LAMP is simple and does not require sophisticated equipment or skilled personnel, but is less sensitive than RT-PCR [52, 54].

The lower respiratory tract sampling techniques such as bronchoalveolar lavage fluid and fiber bronchoscope brush biopsy are considered ideal clinical materials for critically ill patients, due to their higher positive rate on the nucleic acid test [33]. In autopsy lung tissues, the extent of lung damage does not convincingly show a correlation with the virus load, with a tendency to lower viral RNA copy numbers in latestage disease $[20,22]$. For morphological detection of SARS-CoV-2 in tissues, immunohistochemical stains for the spike glycoprotein and membrane and/or envelope proteins and viral RNA identification using the highly sensitive RNAscope technique have been developed $[55,56]$.

\section{Pathomechanisms of pulmonary COVID-19}

At early stages of the pandemic, post-mortem examinations of COVID-19 patients revealed DAD with severe capillary congestion, microthrombosis, and thrombosis of small to midsized arteries as well as pulmonary thromboembolism suggesting vascular dysfunction [12, 57-59]. These features may explain the more specific ARDS phenotype observable in coronavirus-induced ALI with its dissociation between the relatively well-preserved lung mechanics and the severity of hypoxemia, which has been suspected to be caused by impaired regulation of pulmonary blood flow [60]. In this section, we will summarize what has been recently elucidated respecting the pathophysiology of SARS-CoV-2 interaction with the lung parenchyma and the cascade of local COVID19 inflammatory response and endothelial and vascular damage leading to deleterious DAD, thromboinflammation, neutrophilic and macrophage dysfunction, immunopathology, and intussusceptive angiogenesis. Nevertheless, we are aware of the fact that the pathophysiology of pulmonary COVID-19 is a young and rapidly evolving field, and much of the information given below is likely to be modified with ongoing research. Furthermore, many of the pathogenetic events and mechanisms are likely not specific for COVID-19, but may be found in ALI of other causes, including other viral infections.

The virus itself is directly involved in the pathogenesis of pulmonary disease; e.g., binding of viral spike protein reduces ACE2 expression and per se drives ALI, leading to the excessive production of angiotensin II, which in turn increases pulmonary vascular permeability $[61,62]$. Whether due to direct viral infection of endothelial cells, as discussed above, or related to immunopathology with subsequent activation of thrombotic pathways, the vasculature of the lung appears to be crucial in the pathogenesis of COVID-19, as has been 
recently reviewed [63], and leads to the characteristic microthrombosis of the capillary network of the alveoli (Fig. 2) and thrombosis of pulmonary arteries/arterioles.

\section{Hyperactivation of innate immunity}

Virally induced hyperactivation of innate immunity at the level of respiratory membranes is suggested to play a major role in so-called hyper-inflammatory ARDS [64]. As in other viral infections, the innate immune response against SARS-CoV-2 is initiated by pathogens and their associated molecular patterns (PAMP) that are recognized by pattern recognition receptors (PPR), such as Toll-like receptors 3, 7, and 8 (TLR3, TLR7, TLR8) on airway epithelial cells, tissue resident macrophages, and dendritic cells [65]. These cells then initiate inflammatory pulmonary response, mainly by an upregulation of type I interferons (IFN) and interferon-stimulated genes (ISG), which is quite pronounced in early high-viral-load disease [30]; importantly yet beyond of the scope of this review, impairment of type I IFN antiviral response seems to be crucial for COVID-19 severity [66, 67]. This response can further foster epithelial and endothelial damage, as reviewed in [68], e.g., by negatively impacting on cell adhesion junctions, particularly on VE-cadherin, resulting in "loosening" of the bonds between endothelial cells [69] that leads to increased vascular permeability, a key feature of exudative ARDS [70]. Indeed, pulmonary edema and capillarostasis are the most commonly observable microscopic changes in COVID-19 [12], and CDH5 (encoding for VE-cadherin) is among the downregulated genes in COVID-19 [21]. In addition, the ability of pneumocytes to absorb the excess fluid from the alveolar space through active sodium transport is impaired leading to edema [71]. The edema fosters hyaline membrane formation and surfactant dysfunction in exudative $\mathrm{DAD}$, which is typically followed by hyperplasia of type 2 pneumocytes, initiating the proliferative phase of DAD [70]. Thus, these pneumocytes become functionally impaired to produce surfactant [72] on top of being additionally severely compromised being infected by SARS-CoV-2. This may explain the proposed link virus- especially coronavirus-induced DAD and antiphospholipid syndromes [73, 74], observable in some COVID-19 patients $[75,76]$ that may also directly connect ALI to coagulation.

\section{Endothelial and vascular damage}

There is substantial evidence of profound endothelial damage in COVID-19. Coagulation factor VIII, von-Willebrandfactor (vWF), and angiopoietin 2 (Ang-2), which are stored in the Weibel-Palade bodies of endothelial cells and are released upon cell injury [77], are increased in COVID-19 [63]. Ang-2 (Ang-2) serves as an antagonist of Ang-1 and inhibits its antiinflammatory, anticoagulatory, and antiapoptotic signaling [78]; importantly, Ang-2 is directly linked to ALI and increases pulmonary vascular permeability [79], and its levels correlate with prognosis in COVID-19 [80]. COVID-19 patients have significantly elevated vWF [81], which can spontaneously bind platelets and lead to microthrombosis, and may mechanistically link the overrepresentation of blood group A individuals among severe COVID-19 [12, 82], as vWF levels are known to be higher in such individuals. Thus, it is not surprising that COVID-19 patients often initially present with increased fibrinogen levels, increased D-dimers, and suffer-as described above-from significant thrombotic complications [83]. The damaged endothelial cells lose their ability to maintain physiological functions, especially their antithrombotic activity at the luminal surface (e.g., CD39, prostaglandin 2, tissue factor pathway inhibitor), their production of tissue plasminogen activator, and NO [63]. Interestingly, there is a statistically significant link between decreased COVID-19 mortality and the distribution of improved-productivity NOS3 haplotypes (the gene encoding for endothelial nitric oxide synthase) [84]. On top of losing its antithrombotic properties, the endothelium activated by inflammatory signals exerts an opposite battery of functions [85] by actively producing thromboxane, antiplasmin, and plasminogen activator inhibitor-1 (PAI-1). Indeed, the genes SERPINF1 and SERPINE1 encoding for $\alpha 2$-antiplasmin and PAI-1 are among the top upregulated genes in lethal COVID19 [21]. Thus and irrespective of potential direct viruscytopathic effects on endothelial cells, extensive thrombosis of pulmonary vessels is a predictable and consistently detectable finding. Such thrombosis would be expected to disrupt the physiological gas exchange, contributing to COVID-19associated ALI with its characteristic hypo- to normocapnic hypoxia/"happy hypoxia" [86]. $\mathrm{CO}_{2}$ diffuses about 20 times more easily through tissues than $\mathrm{O}_{2}$ and is transported in the blood mainly ( $80 \%)$ as bicarbonate dissolved in plasma, the flow of which is less affected in COVID-19.

A further aspect first noticed by Magro et al. [87] features complement deposition together with neutrophil infiltration in the interalveolar septal space. Indeed, it was highly likely that complement-mediated microangiopathy might be involved in COVID-19, as it has been involved in SARS-CoV-associated ALI and in ARDS in general $[88,89]$. The complement system further contributes to increased permeability of pulmonary capillaries, with subsequent fluid leakage in the alveolar space, recruitment of immune cells, and stimulation of proinflammatory cytokine production. Interestingly, while SERPING1 encoding for the $\mathrm{C} 1$ esterase inhibitor is generally upregulated in COVID-19, C1QA,C1QB,C2, and $C 3$ encoding for the respective complement compounds are upregulated, in late low-viral-load instances in particular [21, 30]. The generated $\mathrm{C} 5 \mathrm{a}$ is a potent chemotactic agent that leads to neutrophilic recruitment and increased vascular permeability in ALI [90]. Thus, the pathogenesis of lethal 
COVID-19 features a self-perpetuating process of thromboinflammation that links endothelial injury of the alveolar capillary network and other lung vessels to DAD, thrombotic microangiopathy, thrombosis of small- to mid-sized arteries, and staffing of inflammatory cells [91]. The latter, particularly neutrophils, play a key role in further (collateral) damage by releasing several toxic mediators [70] such as reactive oxygen species, and generation of NET [92]. These NET, which consist of DNA and citrullinated histones, mount antimicrobial effects and are found to cause severe tissue injury, coagulopathy, and barrier dysfunction in ARDS in general [93], and in SARS-CoV-2-induced ALI in particular [94]. Importantly, one of the NET markers, MPO-DNA correlates with elevated absolute neutrophilic count (one of the best predictors of disease severity), decreased $\mathrm{PaO}_{2} / \mathrm{FiO}_{2}$ ratio, a need for mechanical ventilation, and death in COVID-19 [95]. Dysregulated NETosis has been shown to also cause immunothrombosis in response to other respiratory viruses [93] by prothrombotic reprogramming of endothelial cells [96] and trapping the tissue factor pathway inhibitor.

Taken together, these findings point to the central role of vascular damage in the pathogenesis of COVID-19-related ALI as well as COVID-19-related organ damage in general that is meanwhile confirmed by multiple levels of evidence [97].

\section{The role of macrophages in lung injury}

Resident macrophages of the lungs and those recruited from the circulation play an essential role in ARDS initiation, development, and resolution [70]. They are the primary sensor cells of PAMP through their PPR, which lead to increased intracellular BTK phosphorylation and NF- $\mathrm{BB}$ signaling in the context of COVID-19 [98], and are one of the most important sources of e.g. CXCL8, which is a potent chemoattractant for neutrophils (CXCL8 being overexpressed in high-viral-load COVID-19 [21]). Macrophages are well known to terminate and resolve inflammatory ALI and coordinate structural and functional parenchymal repair processes that are essential for return to homeostasis [99]. In proliferative DAD, the macrophages shift from an M1 to an M2 phenotype to secrete antiinflammatory cytokines and to clear debris [100]. In line with the known role of these cells in ALI, bronchoalveolar lavages of patients with severe COVID-19 contained higher proportions of macrophages, yet surprisingly most of them were monocyte-derived macrophages instead of alveolar macrophages, which indicates a possible macrophage activation [101, 102]. These macrophages express chemokines (CCL2, CCL3, and CXCL10) and inflammatory transcription factors (STAT1, STAT2, ISG), which we similarly observed in high-virus-load (early) COVID-19 autopsy lungs. Importantly, the genes encoding for CXCL10 and its receptor $\mathrm{CXCR} 3$, which are highly chemotactic for (particularly M1) macrophages, are among the most consistently upregulated in high-virus-load COVID-19 [21, 30], while in low-virus-load, late-stage COVID-19, there is a distinct upregulation of CD163, SPP1, TGFBI, and F13A that are all considered markers of M2 macrophages. In line, a subset of alternative M2 macrophages expressing especially profibrotic genes (TREM2, TGFB1, and SPP1) was also identified in patients with severe COVID-19 [101]. All these findings suggest a significant pathogenic role of macrophages/ macrophage activation in critical COVID-19 cases that may extend beyondinflammation [103], paving the way towards pulmonary fibrosis (see below) and macrophage activation syndrome/hemophagocytosis [104]. Indeed, compared to control lungs from various inflammatory conditions, COVID-19 autopsy lungs contain high amounts of $\mathrm{CD} 163^{+}$and $\mathrm{CD} 206^{+}$ (all likely M2) macrophages (Fig. 2), and the draining lymph nodes contain high amounts of histiocytes with hemophagocytic activity and some COVID-19 patients suffer from hemophagocytic lymphohistiocytosis [105, 106].

\section{Cytokine dysregulation and vascular remodeling}

Most data implicate cytokine dysregulation as a central factor in COVID-19 immuno(patho)logy, extending beyond the scope of this review [107]. Aberrant IFN- $\gamma$ release has been previously shown to lead to epithelial and endothelial cell apoptosis and vascular leakage, suboptimal $\mathrm{T}$ cell response, accumulation of alternatively activated macrophages, altered tissue homeostasis, and ARDS [108]. Similarly, dysregulated TNF- $\alpha$ release results in apoptosis-promoting effects on highly activated effector T cells [109], and also increases the adhesion of lymphocytes in ALI by activating the SDF1(CXCL12)/CXCR4 pathway [110], possibly also explaining decreased T cell counts (lymphopenia) in severe COVID-19. Importantly and again linking cytokines to vascular damage, CXCR4/CXCL12 signaling has been identified as potential molecular regulator of intussusceptive angiogenesis [111]. This is a unique, rapid, VEGF-independent mechanism of angiogenesis by splitting vessels into two separate lumina, incorporating circulating angiogenic cells. It acts as a physiological reaction to maintain blood flow in prolonged inflammation and is uniformly observable in early and late COVID19 [21] (Fig. 2). Intussusceptive angiogenesis may represent a common pathophysiological denominator linking the still inestimable long-term COVID-19 complications to fibrotic interstitial lung disease [112], and-given the number of genes encoding for proteins involved in scarring that are upregulated in COVID-19 [21] - this might truly be highly relevant. Indeed, $C X C R 4$ is among the upregulated genes of both high- and low-viral-load COVID-19 [30], while EPHRIN genes, ERG, EGR3, and NOTCH3 encoding for important regulators of sprouting angiogenesis, are downregulated in COVID-19 (own unpublished data and [21]). Blood flow, 
whether stable laminar or disturbed low/oscillatory (Fig. 2, part 8), is highly dependent on the morphology of the blood vessels and defines vascular shear stress [113]. While high fluid shear stress in laminar flow is angioprotective promoting endothelial cell survival, vasodilation, and anticoagulation, low shear stress results in vasoconstriction, platelet aggregation, coagulation, and pathological reshaping of microvascular architecture [112]. Indeed, analysis of known genes encoding for proteins involved in fluid shear stress suggests profound dysregulation in COVID-19 that may warrant future investigation.

\section{Conclusion}

The COVID-19 pandemic has highlighted the critical importance of histopathologic examination of tissues, especially in the setting of clinical autopsies, for elucidating pathomechanisms and underlying causes of death in emerging diseases. Given the massive extent of the pandemic, significant efforts have been made to maximize the information gained from post-mortem examinations in fatal COVID-19. International collaborative networks and autopsy registers aim at speeding up the rate of generation and dissemination of knowledge about this novel disease [114]. A better understanding of pathophysiology, to which tissue-based examination can substantially contribute as emphasized in this review, is of prime importance for improving therapies and prognosis of patients with severe COVID-19.

Acknowledgements The authors thank Massimo Granai for helping with the photomicrographs.

Author contributions All authors have contributed in writing the manuscript and have approved the final version.

Funding Open Access funding enabled and organized by Projekt DEAL. This work was supported in part by special funds from the Federal State of Baden-Württemberg for autopsy-based COVID-19 research (HB and FF), by the Botnar Research Centre for Child Health (BRCCH) Basel (MSM and AT), and Basel and Swiss National Science Foundation (SNSF; Grant No. 320030_189275) (MSM).

\section{Declarations}

Ethics approval The authors state that they comply with the ethical standards specified by Virchows Archive.

Conflict of interest The authors declare no conflict of interest.

Open Access This article is licensed under a Creative Commons Attribution 4.0 International License, which permits use, sharing, adaptation, distribution and reproduction in any medium or format, as long as you give appropriate credit to the original author(s) and the source, provide a link to the Creative Commons licence, and indicate if changes were made. The images or other third party material in this article are included in the article's Creative Commons licence, unless indicated otherwise in a credit line to the material. If material is not included in the article's Creative Commons licence and your intended use is not permitted by statutory regulation or exceeds the permitted use, you will need to obtain permission directly from the copyright holder. To view a copy of this licence, visit http://creativecommons.org/licenses/by/4.0/.

\section{References}

1. Wu F, Zhao S, Yu B, Chen YM, Wang W, Song ZG, Hu Y, Tao ZW, Tian JH, Pei YY, Yuan ML, Zhang YL, Dai FH, Liu Y, Wang QM, Zheng JJ, Xu L, Holmes EC, Zhang YZ (2020) A new coronavirus associated with human respiratory disease in China. Nature 579:265-269. https://doi.org/10.1038/s41586020-2008-3

2. Maiese A, Manetti AC, La Russa R, Di Paolo M, Turillazzi E, Frati P, Fineschi V (2020) Autopsy findings in COVID-19-related deaths: a literature review. Forensic Sci Med Pathol. https://doi. org/10.1007/s12024-020-00310-8

3. Omori R, Matsuyama R, Nakata Y (2020) The age distribution of mortality from novel coronavirus disease (COVID-19) suggests no large difference of susceptibility by age. Sci Rep 10:16642. https://doi.org/10.1038/s41598-020-73777-8

4. Magadum A, Kishore R (2020) Cardiovascular manifestations of COVID-19 infection. Cells 9. https://doi.org/10.3390/ cells9112508

5. Yang J, Tian C, Chen Y, Zhu C, Chi H, Li J (2020) Obesity aggravates COVID-19: an updated systematic review and metaanalysis. J Med Virol. https://doi.org/10.1002/jmv.26677

6. Guan WJ, Ni ZY, Hu Y, Liang WH, Ou CQ, He JX, Liu L, Shan H, Lei CL, Hui DSC, Du B, Li LJ, Zeng G, Yuen KY, Chen RC, Tang CL, Wang T, Chen PY, Xiang J, Li SY, Wang JL, Liang ZJ, Peng YX, Wei L, Liu Y, Hu YH, Peng P, Wang JM, Liu JY, Chen Z, Li G, Zheng ZJ, Qiu SQ, Luo J, Ye CJ, Zhu SY, Zhong NS, China Medical Treatment Expert Group for C (2020) Clinical characteristics of coronavirus disease 2019 in China. N Engl J Med 382:1708-1720. https://doi.org/10.1056/NEJMoa2002032

7. Basso C, Calabrese F, Sbaraglia M, Del Vecchio C, Carretta G, Saieva A, Donato D, Flor L, Crisanti A, Dei Tos AP (2020) Feasibility of postmortem examination in the era of COVID-19 pandemic: the experience of a Northeast Italy University Hospital. Virchows Arch 477:341-347. https://doi.org/10.1007/s00428020-02861-1

8. D'Onofrio V, Donders E, Vanden Abeele ME, Dubois J, Cartuyvels R, Achten R, Lammens M, Dendooven A, Driessen A, Augsburg L, Vanrusselt J, Cox J (2020) The clinical value of minimal invasive autopsy in COVID-19 patients. PLoS One 15: e0242300. https://doi.org/10.1371/journal.pone.0242300

9. Li Y, Wu J, Wang S, Li X, Zhou J, Huang B, Luo D, Cao Q, Chen Y, Chen S, Ma L, Peng L, Pan H, Travis WD, Nie X (2020) Progression to fibrosing diffuse alveolar damage in a series of 30 minimally invasive autopsies with COVID-19 pneumonia in Wuhan, China. Histopathology. https://doi.org/10.1111/his.14249

10. Calabrese F, Pezzuto F, Fortarezza F, Hofman P, Kern I, Panizo A, von der Thusen J, Timofeev S, Gorkiewicz G, Lunardi F (2020) Pulmonary pathology and COVID-19: lessons from autopsy. The experience of European Pulmonary Pathologists. Virchows Arch 477:359-372. https://doi.org/10.1007/s00428-020-02886-6

11. Lax SF, Skok K, Zechner P, Kessler HH, Kaufmann N, Koelblinger C, Vander K, Bargfrieder U, Trauner M (2020) Pulmonary arterial thrombosis in COVID-19 with fatal outcome : results from a prospective, single-center, clinicopathologic case 
series. Ann Intern Med 173:350-361. https://doi.org/10.7326/ M20-2566

12. Menter T, Haslbauer JD, Nienhold R, Savic S, Hopfer H, Deigendesch N, Frank S, Turek D, Willi N, Pargger H, Bassetti S, Leuppi JD, Cathomas G, Tolnay M, Mertz KD, Tzankov A (2020) Postmortem examination of COVID-19 patients reveals diffuse alveolar damage with severe capillary congestion and variegated findings in lungs and other organs suggesting vascular dysfunction. Histopathology 77:198-209. https://doi.org/10. 1111/his. 14134

13. Wichmann D, Sperhake JP, Lutgehetmann M, Steurer S, Edler C, Heinemann A, Heinrich F, Mushumba H, Kniep I, Schroder AS, Burdelski C, de Heer G, Nierhaus A, Frings D, Pfefferle S, Becker $\mathrm{H}$, Bredereke-Wiedling $\mathrm{H}$, de Weerth A, Paschen HR, Sheikhzadeh-Eggers S, Stang A, Schmiedel S, Bokemeyer C, Addo MM, Aepfelbacher M, Puschel K, Kluge S (2020) Autopsy findings and venous thromboembolism in patients with COVID-19: a prospective cohort study. Ann Intern Med 173:268277. https://doi.org/10.7326/M20-2003

14. Kommoss FKF, Schwab C, Tavernar L, Schreck J, Wagner WL, Merle U, Jonigk D, Schirmacher P, Longerich T (2020) The pathology of severe COVID-19-related lung damage. Dtsch Arztebl Int 117:500-506. https://doi.org/10.3238/arztebl.2020.0500

15. Schaller T, Hirschbuhl K, Burkhardt K, Braun G, Trepel M, Markl B, Claus R (2020) Postmortem examination of patients with COVID-19. JAMA 323:2518-2520. https://doi.org/10.1001/ jama.2020.8907

16. Polak SB, Van Gool IC, Cohen D, von der Thusen JH, van Paassen J (2020) A systematic review of pathological findings in COVID-19: a pathophysiological timeline and possible mechanisms of disease progression. Mod Pathol 33:2128-2138. https:// doi.org/10.1038/s41379-020-0603-3

17. Ye Z, Zhang Y, Wang Y, Huang Z, Song B (2020) Chest CT manifestations of new coronavirus disease 2019 (COVID-19): a pictorial review. Eur Radiol 30:4381-4389. https://doi.org/10. 1007/s00330-020-06801-0

18. Pernazza A, Mancini M, Rullo E, Bassi M, De Giacomo T, Rocca CD, d'Amati G (2020) Early histologic findings of pulmonary SARS-CoV-2 infection detected in a surgical specimen. Virchows Arch 477:743-748. https://doi.org/10.1007/s00428020-02829-1

19. Tian S, Hu W, Niu L, Liu H, Xu H, Xiao SY (2020) Pulmonary pathology of early-phase 2019 novel coronavirus (COVID-19) pneumonia in two patients with lung cancer. J Thorac Oncol 15: 700-704. https://doi.org/10.1016/j.jtho.2020.02.010

20. Bosmuller H, Traxler S, Bitzer M, Haberle H, Raiser W, Nann D, Frauenfeld L, Vogelsberg A, Klingel K, Fend F (2020) The evolution of pulmonary pathology in fatal COVID-19 disease: an autopsy study with clinical correlation. Virchows Arch 477:349357. https://doi.org/10.1007/s00428-020-02881-x

21. Ackermann M, Verleden SE, Kuehnel M, Haverich A, Welte T, Laenger F, Vanstapel A, Werlein C, Stark H, Tzankov A, Li WW, Li VW, Mentzer SJ, Jonigk D (2020) Pulmonary vascular endothelialitis, thrombosis, and angiogenesis in COVID-19. N Engl J Med 383:120-128. https://doi.org/10.1056/ NEJMoa2015432

22. Borczuk AC, Salvatore SP, Seshan SV, Patel SS, Bussel JB, Mostyka M, Elsoukkary S, He B, Del Vecchio C, Fortarezza F, Pezzuto F, Navalesi P, Crisanti A, Fowkes ME, Bryce CH, Calabrese F, Beasley MB (2020) COVID-19 pulmonary pathology: a multi-institutional autopsy cohort from Italy and New York City. Mod Pathol 33:2156-2168. https://doi.org/10.1038/s41379020-00661-1

23. Valdivia-Mazeyra MF, Salas C, Nieves-Alonso JM, MartinFragueiro L, Barcena C, Munoz-Hernandez P, Villar-Zarra K, Martin-Lopez J, Ramasco-Rueda F, Fraga J, Jimenez-Heffernan
JA (2020) Increased number of pulmonary megakaryocytes in COVID-19 patients with diffuse alveolar damage: an autopsy study with clinical correlation and review of the literature. Virchows Arch. https://doi.org/10.1007/s00428-020-02926-1

24. Hariri LP, North CM, Shih AR, Israel RA, Maley JH, Villalba JA, Vinarsky V, Rubin J, Okin DA, Sclafani A, Alladina JW, Griffith JW, Gillette MA, Raz Y, Richards CJ, Wong AK, Ly A, Hung YP, Chivukula RR, Petri CR, Calhoun TF, Brenner LN, Hibbert KA, Medoff BD, Hardin CC, Stone JR, Mino-Kenudson M (2021) Lung histopathology in coronavirus disease 2019 as compared with severe acute respiratory sydrome and H1N1 influenza: a systematic review. Chest 159:73-84. https://doi.org/10.1016/j.chest.2020.09. 259

25. Edler C, Schroder AS, Aepfelbacher M, Fitzek A, Heinemann A, Heinrich F, Klein A, Langenwalder F, Lutgehetmann M, Meissner K, Puschel K, Schadler J, Steurer S, Mushumba H, Sperhake JP (2020) Dying with SARS-CoV-2 infection-an autopsy study of the first consecutive 80 cases in Hamburg, Germany. Int J Legal Med 134:1275-1284. https://doi.org/10.1007/s00414-020-02317$\mathrm{w}$

26. Skok K, Vander K, Setaffy L, Kessler HH, Aberle S, Bargfrieder U, Trauner M, Lax SF (2020) COVID-19 autopsies: procedure, technical aspects and cause of fatal course. Experiences from a single-center. Pathol Res Pract 217:153305. https://doi.org/10. 1016/j.prp.2020.153305

27. Pandolfi L, Fossali T, Frangipane V, Bozzini S, Morosini M, D'Amato M, Lettieri S, Urtis M, Di Toro A, Saracino L, Percivalle E, Tomaselli S, Cavagna L, Cova E, Mojoli F, Bergomi P, Ottolina D, Lilleri D, Corsico AG, Arbustini E, Colombo R, Meloni F (2020) Broncho-alveolar inflammation in COVID-19 patients: a correlation with clinical outcome. BMC Pulm Med 20:301. https://doi.org/10.1186/s12890-020-01343-z

28. Bradley BT, Maioli H, Johnston R, Chaudhry I, Fink SL, Xu H, Najafian B, Deutsch G, Lacy JM, Williams T, Yarid N, Marshall DA (2020) Histopathology and ultrastructural findings of fatal COVID-19 infections in Washington State: a case series. Lancet 396:320-332. https://doi.org/10.1016/S0140-6736(20)31305-2

29. Desai N, Neyaz A, Szabolcs A, Shih AR, Chen JH, Thapar V, Nieman LT, Solovyov A, Mehta A, Lieb DJ, Kulkarni AS, Jaicks C, Xu KH, Raabe MJ, Pinto CJ, Juric D, Chebib I, Colvin RB, Kim AY, Monroe R, Warren SE, Danaher P, Reeves JW, Gong J, Rueckert EH, Greenbaum BD, Hacohen N, Lagana SM, Rivera MN, Sholl LM, Stone JR, Ting DT, Deshpande V (2020) Temporal and spatial heterogeneity of host response to SARSCoV-2 pulmonary infection. Nat Commun 11:6319. https://doi. org/10.1038/s41467-020-20139-7

30. Nienhold R, Ciani Y, Koelzer VH, Tzankov A, Haslbauer JD, Menter T, Schwab N, Henkel M, Frank A, Zsikla V, Willi N, Kempf W, Hoyler T, Barbareschi M, Moch H, Tolnay M, Cathomas G, Demichelis F, Junt T, Mertz KD (2020) Two distinct immunopathological profiles in autopsy lungs of COVID-19. Nat Commun 11:5086. https://doi.org/10.1038/s41467-020-18854-2

31. Carsana L, Sonzogni A, Nasr A, Rossi RS, Pellegrinelli A, Zerbi P, Rech R, Colombo R, Antinori S, Corbellino M, Galli M, Catena E, Tosoni A, Gianatti A, Nebuloni M (2020) Pulmonary postmortem findings in a series of COVID-19 cases from northern Italy: a two-centre descriptive study. Lancet Infect Dis 20:11351140. https://doi.org/10.1016/S1473-3099(20)30434-5

32. Del Valle DM, Kim-Schulze S, Huang HH, Beckmann ND, Nirenberg S, Wang B, Lavin Y, Swartz TH, Madduri D, Stock A, Marron TU, Xie H, Patel M, Tuballes K, Van Oekelen O, Rahman A, Kovatch P, Aberg JA, Schadt E, Jagannath S, Mazumdar M, Charney AW, Firpo-Betancourt A, Mendu DR, Jhang J, Reich D, Sigel K, Cordon-Cardo C, Feldmann M, Parekh S, Merad M, Gnjatic S (2020) An inflammatory cytokine 
signature predicts COVID-19 severity and survival. Nat Med 26: 1636-1643. https://doi.org/10.1038/s41591-020-1051-9

33. Polidoro RB, Hagan RS, de Santis SR, Schmidt NW (2020) Overview: systemic inflammatory response derived from lung injury caused by SARS-CoV-2 infection explains severe outcomes in COVID-19. Front Immunol 11:1626. https://doi.org/ 10.3389/fimmu.2020.01626

34. Al-Samkari H, Karp Leaf RS, Dzik WH, Carlson JCT, Fogerty AE, Waheed A, Goodarzi K, Bendapudi PK, Bornikova L, Gupta S, Leaf DE, Kuter DJ, Rosovsky RP (2020) COVID-19 and coagulation: bleeding and thrombotic manifestations of SARS-CoV2 infection. Blood 136:489-500. https://doi.org/10.1182/blood. 2020006520

35. Nagpal P, Narayanasamy S, Vidholia A, Guo J, Shin KM, Lee $\mathrm{CH}$, Hoffman EA (2020) Imaging of COVID-19 pneumonia: patterns, pathogenesis, and advances. Br J Radiol 93:20200538. https://doi.org/10.1259/bjr.20200538

36. Harrison AG, Lin T, Wang P (2020) Mechanisms of SARS-CoV2 transmission and pathogenesis trends. Immunol 41:1100-1115. https://doi.org/10.1016/j.it.2020.10.004

37. Henkel M, Weikert T, Marston K, Schwab N, Sommer G, Haslbauer J, Franzeck F, Anastasopoulos C, Stieltjes B, Michel A, Bremerich J, Menter T, Mertz K, Tzankov A, Sauter A (2020) Lethal COVID-19: Radiological-pathological correlation of the lungs. Radiol Cardiothorac Imaging 2:e200406. https://doi.org/ 10.1148/ryct.2020200406

38. Barisione E, Grillo F, Ball L, Bianchi R, Grosso M, Morbini P, Pelosi P, Patroniti NA, De Lucia A, Orengo G, Gratarola A, Verda M, Cittadini G, Mastracci L, Fiocca R (2020) Fibrotic progression and radiologic correlation in matched lung samples from COVID19 post-mortems. Virchows Arch. https://doi.org/10.1007/ s00428-020-02934-1

39. Lu R, Zhao X, Li J, Niu P, Yang B, Wu H, Wang W, Song H, Huang B, Zhu N, Bi Y, Ma X, Zhan F, Wang L, Hu T, Zhou H, Hu Z, Zhou W, Zhao L, Chen J, Meng Y, Wang J, Lin Y, Yuan J, Xie Z, Ma J, Liu WJ, Wang D, Xu W, Holmes EC, Gao GF, Wu G, Chen W, Shi W, Tan W (2020) Genomic characterisation and epidemiology of 2019 novel coronavirus: implications for virus origins and receptor binding. Lancet 395:565-574. https://doi.org/ 10.1016/S0140-6736(20)30251-8

40. van den Brand JM, Smits SL, Haagmans BL (2015) Pathogenesis of Middle East respiratory syndrome coronavirus. J Pathol 235: 175-184. https://doi.org/10.1002/path.4458

41. Hoffmann M, Kleine-Weber H, Schroeder S, Kruger N, Herrler T, Erichsen S, Schiergens TS, Herrler G, Wu NH, Nitsche A, Muller MA, Drosten C, Pohlmann S (2020) SARS-CoV-2 cell entry depends on ACE2 and TMPRSS2 and is blocked by a clinically proven protease inhibitor. Cell 181:271-280 e278. https://oi. org/10.1016/j.cell.2020.02.052

42. Lee IT, Nakayama T, Wu CT, Goltsev Y, Jiang S, Gall PA, Liao CK, Shih LC, Schurch CM, Mcllwain DR, Chu P, Borchard NA, Zarabanda D, Dholakia SS, Yang A, Kim D, Chen H, Kanie T, Lin CD, Tsai MH, Phillips KM, Kim R, Overdevest JB, Tyler MA, Yan CH, Lin CF, Lin YT, Bau DT, Tsay GJ, Patel ZM, Tsou YA, Tzankov A, Matter MS, Tai CJ, Yeh TH, Hwang PH, Nolan GP, Nayak JV, Jackson PK (2020) ACE2 localizes to the respiratory cilia and is not increased by ACE inhibitors or ARBs. Nat Commun 11:5453. https://doi.org/10.1038/s41467-02019145-6

43. Mossel EC, Wang J, Jeffers S, Edeen KE, Wang S, Cosgrove GP, Funk CJ, Manzer R, Miura TA, Pearson LD, Holmes KV, Mason RJ (2008) SARS-CoV replicates in primary human alveolar type II cell cultures but not in type I-like cells. Virology 372:127-135. https://doi.org/10.1016/j.virol.2007.09.045

44. Skok K, Stelzl E, Trauner M, Kessler HH, Lax SF (2020) Postmortem viral dynamics and tropism in COVID-19 patients in correlation with organ damage. Virchows Arch. https://doi.org/ 10.1007/s00428-020-02903-8

45. Dittmayer C, Meinhardt J, Radbruch H, Radke J, Heppner BI, Heppner FL, Stenzel W, Holland G, Laue M (2020) Why misinterpretation of electron micrographs in SARS-CoV-2-infected tissue goes viral. Lancet 396:e64-e65. https://doi.org/10.1016/ S0140-6736(20)32079-1

46. Tzankov A, Jonigk D (2020) Unlocking the lockdown of science and demystifying COVID-19: how autopsies contribute to our understanding of a deadly pandemic. Virchows Arch 477:331333. https://doi.org/10.1007/s00428-020-02887-5

47. Ko CJ, Harigopal M, Gehlhausen JR, Bosenberg M, McNiff JM, Damsky W (2020) Discordant anti-SARS-CoV-2 spike protein and RNA staining in cutaneous perniotic lesions suggests endothelial deposition of cleaved spike protein. J Cutan Pathol 48:4752. https://doi.org/10.1111/cup.13866

48. Szabolcs M, Sauter JL, Frosina D, Geronimo JA, Hernandez E, Selbs E, Rapkiewicz AV, Rekhtman N, Baine MK, Jager E, Travis WD, Jungbluth AA (2021) Identification of immunohistochemical reagents for in situ protein expression analysis of coronavirusassociated changes in human tissues Appl Immunohistochem. Mol Morphol 29:5-12. https://doi.org/10.1097/PAI. 0000000000000878

49. Varga Z, Flammer AJ, Steiger P, Haberecker M, Andermatt R, Zinkernagel AS, Mehra MR, Schuepbach RA, Ruschitzka F, Moch H (2020) Endothelial cell infection and endotheliitis in COVID-19. Lancet 395:1417-1418. https://doi.org/10.1016/ S0140-6736(20)30937-5

50. Walsh KA, Jordan K, Clyne B, Rohde D, Drummond L, Byrne P, Ahern S, Carty PG, O'Brien KK, O'Murchu E, O'Neill M, Smith SM, Ryan M, Harrington P (2020) SARS-CoV-2 detection, viral load and infectivity over the course of an infection. J Inf Secur 81: 357-371. https://doi.org/10.1016/j.jinf.2020.06.067

51. Seetulsingh P, Kannangara CI, Richman P (2020) Undetectable SARS-CoV-2 in a nasopharyngeal swab but persistent viral RNA from deep lung swabs: findings from an autopsy. BMJ Case Rep 13. https://doi.org/10.1136/bcr-2020-237446

52. Rodel J, Egerer R, Suleyman A, Sommer-Schmid B, Baier M, Henke A, Edel B, Loffler B (2020) Use of the variplex SARSCoV-2 RT-LAMP as a rapid molecular assay to complement RTPCR for COVID-19 diagnosis. J Clin Virol 132:104616. https:// doi.org/10.1016/j.jcv.2020.104616

53. Sethuraman N, Jeremiah SS, Ryo A (2020) Interpreting diagnostic tests for SARS-CoV-2. JAMA 323:2249-2251. https://doi.org/10. 1001/jama.2020.8259

54. Dao Thi VL, Herbst K, Boerner K, Meurer M, Kremer LP, Kirrmaier D, Freistaedter A, Papagiannidis D, Galmozzi C, Stanifer ML, Boulant S, Klein S, Chlanda P, Khalid D, Barreto Miranda I, Schnitzler P, Krausslich HG, Knop M, Anders S (2020) A colorimetric RT-LAMP assay and LAMP-sequencing for detecting SARS-CoV-2 RNA in clinical samples. Sci Transl Med 12. https://doi.org/10.1126/scitranslmed.abc7075

55. Schaefer IM, Padera RF, Solomon IH, Kanjilal S, Hammer MM, Hornick JL, Sholl LM (2020) In situ detection of SARS-CoV-2 in lungs and airways of patients with COVID-19. Mod Pathol 33: 2104-2114. https://doi.org/10.1038/s41379-020-0595-z

56. Magro CM, Mulvey J, Kubiak J, Mikhail S, Suster D, Crowson AN, Laurence J, Nuovo G (2020) Severe COVID-19: a multifaceted viral vasculopathy syndrome. Ann Diagn Pathol 50:151645. https://doi.org/10.1016/j.anndiagpath.2020.151645

57. Martines RB, Ritter JM, Matkovic E, Gary J, Bollweg BC, Bullock H, Goldsmith CS, Silva-Flannery L, Seixas JN, Reagan-Steiner S, Uyeki T, Denison A, Bhatnagar J, Shieh WJ, Zaki SR, Group C-PW (2020) Pathology and pathogenesis of SARS-CoV-2 associated with fatal coronavirus disease, United 
States. Emerg Infect Dis 26:2005-2015. https://doi.org/10.3201/ eid2609.202095

58. Duarte-Neto AN, Monteiro RAA, da Silva LFF, Malheiros D, de Oliveira EP, Theodoro-Filho J, Pinho JRR, Gomes-Gouvea MS, Salles APM, de Oliveira IRS, Mauad T, Saldiva PHN, Dolhnikoff M (2020) Pulmonary and systemic involvement in COVID-19 patients assessed with ultrasound-guided minimally invasive autopsy. Histopathology 77:186-197. https://doi.org/10.1111/his. 14160

59. Fox SE, Akmatbekov A, Harbert JL, Li G, Quincy Brown J, Vander Heide RS (2020) Pulmonary and cardiac pathology in African American patients with COVID-19: an autopsy series from New Orleans. Lancet Respir Med 8:681-686. https://doi. org/10.1016/S2213-2600(20)30243-5

60. Gattinoni L, Chiumello D, Rossi S (2020) COVID-19 pneumonia: ARDS or not? Crit Care 24:154. https://doi.org/10.1186/s13054020-02880-Z

61. Kuba K, Imai Y, Rao S, Gao H, Guo F, Guan B, Huan Y, Yang P, Zhang Y, Deng W, Bao L, Zhang B, Liu G, Wang Z, Chappell M, Liu Y, Zheng D, Leibbrandt A, Wada T, Slutsky AS, Liu D, Qin C, Jiang C, Penninger JM (2005) A crucial role of angiotensin converting enzyme 2 (ACE2) in SARS coronavirus-induced lung injury. Nat Med 11:875-879. https://doi.org/10.1038/nm1267

62. Imai Y, Kuba K, Rao S, Huan Y, Guo F, Guan B, Yang P, Sarao R, Wada T, Leong-Poi H, Crackower MA, Fukamizu A, Hui CC, Hein L, Uhlig S, Slutsky AS, Jiang C, Penninger JM (2005) Angiotensin-converting enzyme 2 protects from severe acute lung failure. Nature 436:112-116. https://doi.org/10.1038/nature03712

63. Iba T, Connors JM, Levy JH (2020) The coagulopathy, endotheliopathy, and vasculitis of COVID-19. Inflamm Res 69: 1181-1189. https://doi.org/10.1007/s00011-020-01401-6

64. Calfee CS, Delucchi K, Parsons PE, Thompson BT, Ware LB, Matthay MA, Network NA (2014) Subphenotypes in acute respiratory distress syndrome: latent class analysis of data from two randomised controlled trials. Lancet Respir Med 2:611-620. https://doi.org/10.1016/S2213-2600(14)70097-9

65. Kikkert M (2020) Innate immune evasion by human respiratory RNA viruses. J Innate Immun 12:4-20. https://doi.org/10.1159/ 000503030

66. Hadjadj J, Yatim N, Barnabei L, Corneau A, Boussier J, Smith N, Pere H, Charbit B, Bondet V, Chenevier-Gobeaux C, Breillat P, Carlier N, Gauzit R, Morbieu C, Pene F, Marin N, Roche N, Szwebel TA, Merkling SH, Treluyer JM, Veyer D, Mouthon L, Blanc C, Tharaux PL, Rozenberg F, Fischer A, Duffy D, RieuxLaucat F, Kerneis S, Terrier B (2020) Impaired type I interferon activity and inflammatory responses in severe COVID-19 patients. Science 369:718-724. https://doi.org/10.1126/science. abc6027

67. Zhang Q, Bastard P, Liu Z, Le Pen J, Moncada-Velez M, Chen J, Ogishi M, Sabli IKD, Hodeib S, Korol C, Rosain J, Bilguvar K, Ye J, Bolze A, Bigio B, Yang R, Arias AA, Zhou Q, Zhang Y, Onodi F, Korniotis S, Karpf L, Philippot Q, Chbihi M, BonnetMadin L, Dorgham K, Smith N, Schneider WM, Razooky BS, Hoffmann HH, Michailidis E, Moens L, Han JE, Lorenzo L, Bizien L, Meade P, Neehus AL, Ugurbil AC, Corneau A, Kerner G, Zhang P, Rapaport F, Seeleuthner Y, Manry J, Masson C, Schmitt Y, Schluter A, Le Voyer T, Khan T, Li J, Fellay J, Roussel L, Shahrooei M, Alosaimi MF, Mansouri D, Al-Saud H, Al-Mulla F, Almourfi F, Al-Muhsen SZ, Alsohime F, Al Turki S, Hasanato R, van de Beek D, Biondi A, Bettini LR, D'Angio M, Bonfanti P, Imberti L, Sottini A, Paghera S, QuirosRoldan E, Rossi C, Oler AJ, Tompkins MF, Alba C, Vandernoot I, Goffard JC, Smits G, Migeotte I, Haerynck F, Soler-Palacin P, Martin-Nalda A, Colobran R, Morange PE, Keles S, Colkesen F, Ozcelik T, Yasar KK, Senoglu S, Karabela SN, RodriguezGallego C, Novelli G, Hraiech S, Tandjaoui-Lambiotte Y, Duval
X, Laouenan C, Clinicians C-S, Clinicians C, Imagine CG, French CCSG, Co VCC, Amsterdam UMCC-B, Effort CHG, Group NUTCI, Snow AL, Dalgard CL, Milner JD, Vinh DC, Mogensen TH, Marr N, Spaan AN, Boisson B, Boisson-Dupuis S, Bustamante J, Puel A, Ciancanelli MJ, Meyts I, Maniatis T, Soumelis V, Amara A, Nussenzweig M, Garcia-Sastre A, Krammer F, Pujol A, Duffy D, Lifton RP, Zhang SY, Gorochov G, Beziat V, Jouanguy E, Sancho-Shimizu V, Rice CM, Abel L, Notarangelo LD, Cobat A, Su HC, Casanova JL (2020) Inborn errors of type I IFN immunity in patients with life-threatening COVID-19. Science 370. https://doi.org/10.1126/science. abd 4570

68. Lupu L, Palmer A, Huber-Lang M (2020) Inflammation, thrombosis, and destruction: the three-headed cerberus of trauma- and SARS-CoV-2-induced ARDS. Front Immunol 11:584514. https:// doi.org/10.3389/fimmu.2020.584514

69. Vestweber D, Winderlich M, Cagna G, Nottebaum AF (2009) Cell adhesion dynamics at endothelial junctions: VE-cadherin as a major player Trends. Cell Biol 19:8-15. https://doi.org/10.1016/ j.tcb.2008.10.001

70. Matthay MA, Zemans RL, Zimmerman GA, Arabi YM, Beitler JR, Mercat A, Herridge M, Randolph AG, Calfee CS (2019) Acute respiratory distress syndrome. Nat Rev Dis Primers 5:18. https://doi.org/10.1038/s41572-019-0069-0

71. Vadasz I, Raviv S, Sznajder JI (2007) Alveolar epithelium and Na, K-ATPase in acute lung injury. Intensive Care Med 33:12431251. https://doi.org/10.1007/s00134-007-0661-8

72. Islam A, Khan MA (2020) Lung transcriptome of a COVID-19 patient and systems biology predictions suggest impaired surfactant production which may be druggable by surfactant therapy. Sci Rep 10:19395. https://doi.org/10.1038/s41598-020-76404-8

73. Maneta-Peyret L, Kitsiouli E, Lekka M, Nakos G, Cassagne C (2001) Autoantibodies to lipids in bronchoalveolar lavage fluid of patients with acute respiratory distress syndrome. Crit Care Med 29:1950-1954. https://doi.org/10.1097/00003246200110000-00017

74. Uthman IW, Gharavi AE (2002) Viral infections and antiphospholipid antibodies. Semin Arthritis Rheum 31:256263. https://doi.org/10.1053/sarh.2002.28303

75. Borghi MO, Beltagy A, Garrafa E, Curreli D, Cecchini G, Bodio C, Grossi C, Blengino S, Tincani A, Franceschini F, Andreoli L, Lazzaroni MG, Piantoni S, Masneri S, Crisafulli F, Brugnoni D, Muiesan ML, Salvetti M, Parati G, Torresani E, Mahler M, Heilbron F, Pregnolato F, Pengo M, Tedesco F, Pozzi N, Meroni PL (2020) Anti-phospholipid antibodies in COVID-19 are different from those detectable in the anti-phospholipid syndrome. Front Immunol 11:584241. https://doi.org/10.3389/fimmu.2020. 584241

76. Zhang Y, Xiao M, Zhang S, Xia P, Cao W, Jiang W, Chen H, Ding X, Zhao H, Zhang H, Wang C, Zhao J, Sun X, Tian R, Wu W, Wu D, Ma J, Chen Y, Zhang D, Xie J, Yan X, Zhou X, Liu Z, Wang J, Du B, Qin Y, Gao P, Qin X, Xu Y, Zhang W, Li T, Zhang F, Zhao Y, Li Y, Zhang S (2020) Coagulopathy and antiphospholipid antibodies in patients with COVID-19. N Engl J Med 382:e38. https://doi.org/10.1056/NEJMc2007575

77. Streetley J, Fonseca AV, Turner J, Kiskin NI, Knipe L, Rosenthal PB, Carter T (2019) Stimulated release of intraluminal vesicles from Weibel-Palade bodies. Blood 133:2707-2717. https://doi. org/10.1182/blood-2018-09-874552

78. Higgins SJ, De Ceunynck K, Kellum JA, Chen X, Gu X, Chaudhry SA, Schulman S, Libermann TA, Lu S, Shapiro NI, Christiani DC, Flaumenhaft R, Parikh SM (2018) Tie2 protects the vasculature against thrombus formation in systemic inflammation. J Clin Invest 128:1471-1484. https://doi.org/10.1172/ JCI97488 
79. Parikh SM, Mammoto T, Schultz A, Yuan HT, Christiani D, Karumanchi SA, Sukhatme VP (2006) Excess circulating angiopoietin-2 may contribute to pulmonary vascular leak in sepsis in humans. PLoS Med 3:e46. https://doi.org/10.1371/journal. pmed.0030046

80. Smadja DM, Guerin CL, Chocron R, Yatim N, Boussier J, Gendron N, Khider L, Hadjadj J, Goudot G, Debuc B, Juvin P, Hauw-Berlemont C, Augy JL, Peron N, Messas E, Planquette B, Sanchez O, Charbit B, Gaussem P, Duffy D, Terrier B, Mirault T, Diehl JL (2020) Angiopoietin-2 as a marker of endothelial activation is a good predictor factor for intensive care unit admission of COVID-19 patients. Angiogenesis 23:611-620. https://doi.org/ 10.1007/s10456-020-09730-0

81. Helms J, Tacquard C, Severac F, Leonard-Lorant I, Ohana M, Delabranche X, Merdji H, Clere-Jehl R, Schenck M, Fagot Gandet F, Fafi-Kremer S, Castelain V, Schneider F, Grunebaum L, Angles-Cano E, Sattler L, Mertes PM, Meziani F, Group CT (2020) High risk of thrombosis in patients with severe SARSCoV-2 infection: a multicenter prospective cohort study Intensive. Care Med 46:1089-1098. https://doi.org/10.1007/ s00134-020-06062-x

82. Severe Covid GG, Ellinghaus D, Degenhardt F, Bujanda L, Buti M, Albillos A, Invernizzi P, Fernandez J, Prati D, Baselli G, Asselta R, Grimsrud MM, Milani C, Aziz F, Kassens J, May S, Wendorff M, Wienbrandt L, Uellendahl-Werth F, Zheng T, Yi X, de Pablo R, Chercoles AG, Palom A, Garcia-Fernandez AE, Rodriguez-Frias F, Zanella A, Bandera A, Protti A, Aghemo A, Lleo A, Biondi A, Caballero-Garralda A, Gori A, Tanck A, Carreras Nolla A, Latiano A, Fracanzani AL, Peschuck A, Julia A, Pesenti A, Voza A, Jimenez D, Mateos B, Nafria Jimenez B, Quereda C, Paccapelo C, Gassner C, Angelini C, Cea C, Solier A, Pestana D, Muniz-Diaz E, Sandoval E, Paraboschi EM, Navas E, Garcia Sanchez F, Ceriotti F, Martinelli-Boneschi F, Peyvandi F, Blasi F, Tellez L, Blanco-Grau A, Hemmrich-Stanisak G, Grasselli G, Costantino G, Cardamone G, Foti G, Aneli S, Kurihara H, ElAbd H, My I, Galvan-Femenia I, Martin J, Erdmann J, Ferrusquia-Acosta J, Garcia-Etxebarria K, IzquierdoSanchez L, Bettini LR, Sumoy L, Terranova L, Moreira L, Santoro L, Scudeller L, Mesonero F, Roade L, Ruhlemann MC, Schaefer M, Carrabba M, Riveiro-Barciela M, Figuera Basso ME, Valsecchi MG, Hernandez-Tejero M, Acosta-Herrera M, D'Angio M, Baldini M, Cazzaniga M, Schulzky M, Cecconi M, Wittig M, Ciccarelli M, Rodriguez-Gandia M, Bocciolone M, Miozzo M, Montano N, Braun N, Sacchi N, Martinez N, Ozer O, Palmieri O, Faverio P, Preatoni P, Bonfanti P, Omodei P, Tentorio P, Castro P, Rodrigues PM, Blandino Ortiz A, de Cid R, Ferrer R, Gualtierotti R, Nieto R, Goerg S, Badalamenti S, Marsal S, Matullo G, Pelusi S, Juzenas S, Aliberti S, Monzani V, Moreno V, Wesse T, Lenz TL, Pumarola T, Rimoldi V, Bosari S, Albrecht W, Peter W, Romero-Gomez M, D'Amato M, Duga S, Banales JM, Hov JR, Folseraas T, Valenti L, Franke A, Karlsen TH (2020) Genomewide association study of severe COVID-19 with respiratory failure. N Engl J Med 383:1522-1534. https://doi.org/10. 1056/NEJMoa2020283

83. Klok FA, Kruip M, van der Meer NJM, Arbous MS, Gommers D, Kant KM, Kaptein FHJ, van Paassen J, Stals MAM, Huisman MV, Endeman H (2020) Confirmation of the high cumulative incidence of thrombotic complications in critically ill ICU patients with COVID-19: an updated analysis. Thromb Res 191:148-150. https://doi.org/10.1016/j.thromres.2020.04.041

84. Guan SP, Seet RCS, Kennedy BK (2020) Does eNOS derived nitric oxide protect the young from severe COVID-19 complications? Ageing Res Rev 64:101201. https://doi.org/10.1016/j.arr. 2020.101201
85. Libby P, Luscher T (2020) COVID-19 is, in the end, an endothelial disease. Eur Heart J 41:3038-3044. https://doi.org/10.1093/ eurheartj/ehaa623

86. Komorowski M, Aberegg SK (2020) Using applied lung physiology to understand COVID-19 patterns. Br J Anaesth 125:250 253. https://doi.org/10.1016/j.bja.2020.05.019

87. Magro C, Mulvey JJ, Berlin D, Nuovo G, Salvatore S, Harp J, Baxter-Stoltzfus A, Laurence J (2020) Complement associated microvascular injury and thrombosis in the pathogenesis of severe COVID-19 infection: a report of five cases. Transl Res 220:1-13. https://doi.org/10.1016/j.trsl.2020.04.007

88. Gralinski LE, Sheahan TP, Morrison TE, Menachery VD, Jensen K, Leist SR, Whitmore A, Heise MT, Baric RS (2018) Complement activation contributes to severe acute respiratory syndrome coronavirus pathogenesis. mBio 9. https://doi.org/10. 1128/mBio.01753-18

89. Zilow G, Joka T, Obertacke U, Rother U, Kirschfink M (1992) Generation of anaphylatoxin C3a in plasma and bronchoalveolar lavage fluid in trauma patients at risk for the adult respiratory distress syndrome. Crit Care Med 20:468-473. https://doi.org/ 10.1097/00003246-199204000-00006

90. Hoth JJ, Wells JD, Jones SE, Yoza BK, McCall CE (2014) Complement mediates a primed inflammatory response after traumatic lung injury. J Trauma Acute Care Surg 76:601-608; discussion 608-609. https://doi.org/10.1097/TA.0000000000000129

91. Lisman T (2018) Platelet-neutrophil interactions as drivers of inflammatory and thrombotic disease. Cell Tissue Res 371:567576. https://doi.org/10.1007/s00441-017-2727-4

92. Sorensen OE, Borregaard N (2016) Neutrophil extracellular traps the dark side of neutrophils. J Clin Invest 126:1612-1620. https:// doi.org/10.1172/JCI84538

93. Porto BN, Stein RT (2016) Neutrophil extracellular traps in pulmonary diseases: too much of a good thing? Front Immunol 7:311. https://doi.org/10.3389/fimmu.2016.00311

94. Zuo Y, Yalavarthi S, Shi H, Gockman K, Zuo M, Madison JA, Blair C, Weber A, Barnes BJ, Egeblad M, Woods RJ, Kanthi Y, Knight JS (2020) Neutrophil extracellular traps (NETs) as markers of disease severity in COVID-19. medRxiv. https://doi.org/10. 1101/2020.04.09.20059626

95. Middleton EA, He XY, Denorme F, Campbell RA, Ng D, Salvatore SP, Mostyka M, Baxter-Stoltzfus A, Borczuk AC, Loda M, Cody MJ, Manne BK, Portier I, Harris ES, Petrey AC, Beswick EJ, Caulin AF, Iovino A, Abegglen LM, Weyrich AS, Rondina MT, Egeblad M, Schiffman JD, Yost CC (2020) Neutrophil extracellular traps contribute to immunothrombosis in COVID-19 acute respiratory distress syndrome. Blood 136: 1169-1179. https://doi.org/10.1182/blood.2020007008

96. Folco EJ, Mawson TL, Vromman A, Bernardes-Souza B, Franck G, Persson O, Nakamura M, Newton G, Luscinskas FW, Libby P (2018) Neutrophil extracellular traps induce endothelial cell activation and tissue factor production through interleukin-1 alpha and cathepsin G. Arterioscler Thromb Vasc Biol 38:1901-1912. https://doi.org/10.1161/ATVBAHA.118.311150

97. Teuwen LA, Geldhof V, Pasut A, Carmeliet P (2020) COVID-19: the vasculature unleashed. Nat Rev Immunol 20:389-391. https:// doi.org/10.1038/s41577-020-0343-0

98. Roschewski M, Lionakis MS, Sharman JP, Roswarski J, Goy A, Monticelli MA, Roshon M, Wrzesinski SH, Desai JV, Zarakas MA, Collen J, Rose K, Hamdy A, Izumi R, Wright GW, Chung KK, Baselga J, Staudt LM, Wilson WH (2020) Inhibition of Bruton tyrosine kinase in patients with severe COVID-19. Sci Immunol 5. https://doi.org/10.1126/sciimmunol.abd0110

99. Herold S, Mayer K, Lohmeyer J (2011) Acute lung injury: how macrophages orchestrate resolution of inflammation and tissue repair. Front Immunol 2:65. https://doi.org/10.3389/fimmu.2011. 00065 
100. Huang X, Xiu H, Zhang S, Zhang G (2018) The role of macrophages in the pathogenesis of ALI/ARDS. Mediat Inflamm 2018: 1264913-1264918. https://doi.org/10.1155/2018/1264913

101. Liao M, Liu Y, Yuan J, Wen Y, Xu G, Zhao J, Cheng L, Li J, Wang X, Wang F, Liu L, Amit I, Zhang S, Zhang Z (2020) Singlecell landscape of bronchoalveolar immune cells in patients with COVID-19. Nat Med 26:842-844. https://doi.org/10.1038/ s41591-020-0901-9

102. Zhang D, Guo R, Lei L, Liu H, Wang Y, Wang Y, Qian H, Dai T, Zhang T, Lai Y, Wang J, Liu Z, Chen T, He A, O'Dwyer M, Hu J (2020) COVID-19 infection induces readily detectable morphologic and inflammation-related phenotypic changes in peripheral blood monocytes. J Leukoc Biol 109:13-22. https://doi.org/10. 1002/JLB.4HI0720-470R

103. Merad M, Martin JC (2020) Pathological inflammation in patients with COVID-19: a key role for monocytes and macrophages. Nat Rev Immunol 20:355-362. https://doi.org/10.1038/s41577-0200331-4

104. Quan C, Li C, Ma H, Li Y, Zhang H (2020) Immunopathogenesis of coronavirus-induced acute respiratory distress syndrome (ARDS): potential infection-associated hemophagocytic lymphohistiocytosis. Clin Microbiol Rev 34. https://doi.org/10. 1128/CMR.00074-20

105. Prilutskiy A, Kritselis M, Shevtsov A, Yambayev I, Vadlamudi C, Zhao Q, Kataria Y, Sarosiek SR, Lerner A, Sloan JM, Quillen K, Burks EJ (2020) SARS-CoV-2 infection-associated hemophagocytic lymphohistiocytosis. Am J Clin Pathol 154: 466-474. https://doi.org/10.1093/ajcp/aqaa124

106. Haslbauer JD, Perrina V, Matter M, Dellas A, Mihatsch MJ, Tzankov A (2020) Retrospective post-mortem SARS-CoV-2 RT-PCR of autopsies with COVID-19-suggestive pathology supports the absence of lethal community spread in Basel, Switzerland, before February 2020. Pathobiology:1-11. https:// doi.org/10.1159/000512563

107. McGonagle D, Sharif K, O'Regan A, Bridgewood C (2020) The role of cytokines including interleukin-6 in COVID-19 induced pneumonia and macrophage activation syndrome-like disease.
Autoimmun Rev 19:102537. https://doi.org/10.1016/j.autrev. 2020.102537

108. Channappanavar R, Perlman S (2017) Pathogenic human coronavirus infections: causes and consequences of cytokine storm and immunopathology. Semin Immunopathol 39:529-539. https://doi. org/10.1007/s00281-017-0629-x

109. Mehta AK, Gracias DT, Croft M (2018) TNF activity and T cells. Cytokine 101:14-18. https://doi.org/10.1016/j.cyto.2016.08.003

110. Trotta T, Di Gioia S, Piro D, Lepore S, Cantatore S, Porro C, Castellani S, Petrella A, Fortunato F, Maffione AB, Conese M (2013) Effect of acute lung injury on VLA-4 and CXCR4 expression in resident and circulating hematopoietic stem/progenitor cells. Respiration 85:252-264. https://doi.org/10.1159/ 000341172

111. Salvucci O, Basik M, Yao L, Bianchi R, Tosato G (2004) Evidence for the involvement of SDF-1 and CXCR4 in the disruption of endothelial cell-branching morphogenesis and angiogenesis by TNF-alpha and IFN-gamma. J Leukoc Biol 76:217226. https://doi.org/10.1189/jlb.1203609

112. Ackermann M, Mentzer SJ, Kolb M, Jonigk D (2020) Inflammation and intussusceptive angiogenesis in COVID-19: everything in and out of flow. Eur Respir J 56:2003147. https:// doi.org/10.1183/13993003.03147-2020

113. Lee GS, Filipovic N, Miele LF, Lin M, Simpson DC, Giney B, Konerding MA, Tsuda A, Mentzer SJ (2010) Blood flow shapes intravascular pillar geometry in the chick chorioallantoic membrane. J Angiogenes Res 2:11. https://doi.org/10.1186/20402384-2-11

114. von Stillfried S, Bulow RD, Rohrig R, Knuchel-Clarke R, Boor P, DeRegCovid (2020) Autopsy registry can facilitate COVID-19 research EMBO Mol Med 12:e12885. 10.15252/ emmm.202012885

Publisher's note Springer Nature remains neutral with regard to jurisdictional claims in published maps and institutional affiliations. 